\title{
ISOLATION AND CHARACTERIZATION OF CELLULOSE NANO FIBER PRODUCING BACTERIAL STRAIN FROM FERMENTED FRUITS
}

\author{
Ahmed Alemam $^{1 *}$, Mamdouh S. El-Gamal ${ }^{1}$,Saad El Din Hassan ${ }^{1}$, Said E. Desouky ${ }^{1}$, \\ Tharwat I. Shaheen ${ }^{2}$. \\ ${ }^{1}$ Department of Botany and microbiology, Faculty of science, Al-Azhar University, \\ Cairo, Egypt \\ ${ }^{2}$ Textile Industries Research Division, National Research Centre, Dokki, Cairo, Egypt \\ *Corresponding Author : ahmed.alemam@azhar.edu.eg
}

\begin{abstract}
A bacterial cellulose (BC) producing strain isolated from fermented fruit. Twenty BC producing bacteria were isolated from each the isolation sources (fermented fruits). The most potent strain was identified to be Komagataeibacter xylinus SB3.1 based on several morphological characteristics, biochemical tests and 16srRNA. The Komagataeibacter xylinus SB3.1. was produce BC within $\mathrm{pH}$ 4-9 and exhibit maximum $\mathrm{BC}$ production $(2.4 \mathrm{~g} / \mathrm{L})$ at $\mathrm{pH} 6$ in under static conditions for 7 days. The structure of BC produced from the tested strains was assayed by scanning electron microscope it was revealed the diameter of thin ribbons ranged from $34.34 \mathrm{~nm}$ to 39.16 $\mathrm{nm}$ and exhibits higher porosity (81.5\%).In comparison with the specimen from model BC producer, Gluconacetobacter xylinus 10245. Based on these analyses, the isolated Komagataeibacter xylinus SB3.1 can efficiently produce BC, which can be applied for industrial manufacturing with potential features.
\end{abstract}

Keywords: Bacterial Cellulose; Komagataeibacter xylinus , Nanocellulose , Acetobacter and fermented fruits. 


\section{Introduction}

Bacterial cellulose (BC) is a promising natural polymer belongs to specific products of primary metabolism (Retegi et al.2010). Cellulose is synthesized by bacteria belongs to the genera of Acetobacter, Rhizobium, Agrobacterium, Psuedomonas and Sarcina (Vu et al. 2008). Many strain of A. xylinum are capable of producing cellulose in varying amounts and growing on wide varieties of substrates like glucose, sucrose, fructose, invert sugar, ethanol and glycerol (White and Brown 1989). Cellulose production by Acetobacter xylinum had been noted both in static as well as agitated cultures (Chao et al. 2000). The most efficient producer is gram-negative and acetic acid bacteria, Acetobacter xylinum (reclassified as Komagataeibacter xylinum) (Yamada et al.2011). The bacteria was applied as a model microorganism for basic and applied studies on cellulose. Acetobacter xylinum is widely distributed in nature and is a common contaminant in the industrial production of vinegar by Acetobacter aceti. Acetobacter xylinum has been isolated from rotting fruits, vegetables and by fermenting coconut water (Jagannath et al.2008)

Presently $\mathrm{BC}$ is receiving great attention and being widely investigated as a new type of scaffold material due to its fine fiber network, biocompatibility, high water holding capacity, high tensile strength (Putra et al.2008), high crystalline, high degree of polymerization, high purity, elasticity, durability, non -toxic and non- allergic (Hei,1999,Backdahl et al.2006, Sherif and Kazuhiko 2006,El-Saied et al.2008, Liet et al.2009, Marzieh and Ali 2010,Denise et al.2011). In food applications the BC was used as an additive, emulsifier, dietary fiber, edible preservative and as a barrier against bacterial growth (Pacheco et al. 2004, Denise $\boldsymbol{e t}$ al. 2011). Recently, BC is used in many special applications such as a scaffold for tissue engineering of cartilages and blood vessels (Yamanaka et al.1990, Klemn $\boldsymbol{e t}$ al.1999 and 2001), as well as for artificial skin for temporary covering of wounds (Krystynowicz and Bieleck 2001). Purified and dried BC was converted to a membrane to be used in the separation processes such as ultrafilteration, gas permeation and vapor permeation, and used in paper manufacture (Luz et al.2006, Kuan et al.2009).

The aim of the current investigations was to a new BC-producing strain from fermented fruit juice. The isolated strain was characterized based on colony morphology, specific biochemical tests and 16S r-DNA sequence analyses. The cellulose production ability of isolated strain was compared using six different types of culture media. The $\mathrm{BC}$ production abilities at different initial $\mathrm{pHs}$ were investigated. The materials properties of the produced $\mathrm{BC}$ such as morphology, and porosity were also evaluated.

\section{Materials and Methods}

\section{Chemicals and Reagents}

All chemicals used in present investigation were analytical grade and purchased from Hi-media, Sigma- Aldrich, Ranbaxy and Merck. 


\subsection{Fermented fruit juice preparation}

Various fruits (pineapple, apple and guava) were purchased from local market in Cairo Egypt. Approximately $200 \mathrm{~g}$ of fruit dices were added to $1 \mathrm{~L}$ water containing 100 $\mathrm{g}$ of granulated sugar and $100 \mathrm{~g}$ of brown sugar. The mixed solution was stored at room temperature with a cover. After 10 days, a gelatinous membrane floated on the surface of the solution.

\subsection{Isolation of BC-producing strain}

The gelatinous membrane was homogenized using a waring blender 7011HS (Osaka Chemical Co. Ltd., Osaka, Japan), and then added 10\% into HS medium at 28 ${ }^{\circ} \mathrm{C}$, and spread onto Hestrin and Schramm (HS) (Hestrin \& Schramm, 1954) agar (20 g of d-glucose, $5 \mathrm{~g}$ of peptone, $5 \mathrm{~g}$ of yeast extract, $2.7 \mathrm{~g}$ of $\mathrm{Na}_{2} \mathrm{HPO}_{4}, 0.115 \mathrm{~g}$ of citric acid and $15 \mathrm{~g}$ of agar in $1 \mathrm{~L}$ deionic water) for 7 days. The single colony was picked to inoculate into 96-well plate with HS medium (same as HS agar without $15 \mathrm{~g}$ of agar) for 7 days. In $\mathrm{pH}$ resistant experiment, HS medium was used as base medium and adjusted to the desired final $\mathrm{pH}$ value $(4-10)$ with $\mathrm{HCl}$ or $\mathrm{NaOH}$. Finally, each cellulose producing strain was selected for further analysis.

\subsection{Identification of $\mathrm{BC}$-producing strain}

Morphological, physical and biochemical analyses were carried out according to Bergey's Manual of Systematic Bacteriology (Brenneretal.,2004). Colony morphology such as Gram staining, production of catalase, production of water soluble pigment, oxidation of acetate or lactate, growth in the presence of $0.35 \%$ acetic acid, growth on $3 \%(\mathrm{v} / \mathrm{v})$ ethanol in the presence of $5 \%$ acetic acid, requirement of acetic acid for growth, growth only in the presence of acetic acid, ethanol and glucose, growth on the medium of Carr and Passmore, growth on carbon source ethanol, growth in the presence of $30 \%(\mathrm{w} / \mathrm{v})$ glucose and production of cellulose were evaluated. Acetobacter xylinum was used as the reference strain for biochemical characteristics (Brenner et al., 2004). The selected strains were also identified by using 16s rDNA sequencing. and genomic DNA was extracted for PCR on 16S rDNA with the forward primer: 5AGAGTTTGATCCTGGCTCAG-3, and the reverse primer: 5TACGGCTACCTTGTTACGACTT-3 PCR products were purified and sequenced by Sangon Biotech Co., Ltd. (Shanghai, China) The sequencing results were submitted to BlastN for sequence alignment and homology comparisons against the NCBI GenBank data- base. The $16 \mathrm{~S}$ rDNA of representative species were used for multiple sequence alignment with ClustalX software and the phylogenetic tree was constructed by MEGA 7.0 based on the Neighbor-Joining method with bootstrapping 1000 times

\subsection{Influence of different culture media for cellulose production}

Six types of media were tested for comparing the total yield (dry weight basis) of $\mathrm{BC}$ by the bacterial isolate. The compositions of various media ( $\mathrm{pH}$ adjusted to 5-6) are as follows: 
HS medium (Hestrin and Schramm, 1954), complex medium(COM), (Kamide et al.,1990), Gluconobacteroxydans medium(DSM) (Timke $\boldsymbol{e t}$ al.,2005), sterile distilled water supplemented with ethanol (4\%), SEED medium (Sudsakda et al.,2007), and glucose-ethanol acetic acid medium(GAM) (Hanmoungjai $\boldsymbol{e t}$ al, 2007), sterile distilled water supplemented with ethanol (4\%), SEED medium (Sudsakda et al.,2007), and glucose-ethanol acetic acid medium(GAM) (Hanmoungjai et al, 2007), GEM medium (Son et al., 2002) were used throughout this investigation for bacterial cellulose production. The optical density of cell growth (O.D/620nm) was measured and the pellicle formed at the air-liquid interface of the production medium was collected and rinsed with water for two to three times. It was then treated with $1 \mathrm{~N} \mathrm{NaOH}$ at $80^{\circ} \mathrm{C}$ for 20 min. to neutralize $\mathrm{NaOH}$, the pellicle was treated with $5 \%$ acetic acid solution. It was again washed with water for three times. The purified pellicle obtained was dried at $60^{\circ} \mathrm{C}$ until a constant weight and expressed as $\mathrm{g} / \mathrm{l}$ dry $\mathrm{BC}$ weight, and cellulose yield (\%) was calculated, according to Gamal et al. (1991).

Yield $(\%)=\frac{\text { Dry cellulose production }(\mathrm{g} / \mathrm{l})}{\text { Original Sugar }(\mathrm{g} / 1)} \times 100$

\subsection{Effect of initial pH}

The selected strain was also incubated into HS medium with different $\mathrm{pH}$ conditions (4-10) for 7-day cultivation to confirm the effects of initial $\mathrm{pH}$ value for BC production. Porosity was calculated using the equation of Kouda et al. (1997)

Porosity $\%=($ wet weight - dry weight $) /$ (wet weight - weight in water) $\mathrm{x} 100$. Dried bacterial cellulose membranes were soaked in deionizer water for more than $12 \mathrm{~h}$ at room temperature, and the weight in water was measured by harnessing the sample in advice which suspended the sample in water (Al-shamary and Darwash, 2013).

\subsection{Scanning Electron Microscopy (SEM)}

BC films were frozen at $-80{ }^{\circ} \mathrm{C}$ for 24 hours and freeze-dried for 72 hours. The pellicles were metalized by platinum sputtering and analyzed by scanning electron microscopy (SEM) on a Zeiss DSM-940A microscope at $30 \mathrm{keV}$. The diameter of 50 nanofibers was determined using the ImageJ program (National Institute of Health$\mathrm{NIH})$

\subsection{Statistical analyses}

Statistical evaluation of all experimental data (variation from basal values) were performed using ANOVA.All pairwise-multiple comparisons were performed using Holm-Sidak test. This test is more powerful to detect differences than Tukey's and Bonferroni's tests and is recommended as the first line procedure for most multiple comparisons testing (Systat Software, 2011) SigmaPlot ${ }^{\circledR} 12.5$ software extended with a statistical package and Graphs were plotted in Microsoft ${ }^{\mathrm{TM}}$ Excel ${ }^{\circledR} 2013$ was used. The graphed values are represented as means and error bars. The error bar represents the standard error means calculated from standard deviations. USA) $(\mathrm{p}<0.05)$ 


\section{Results and Discussion}

\subsection{Isolation and identification of cellulose-producing strain.}

Twenty bacterial strains producing a $\mathrm{BC}$ pellicle on the HS medium were obtained from three fermented fruits after streaking on the HS agar medium, colony shapes were shown to be similar to those of reference strains, which was Gram negative. All the isolates were examined for the BC productivity in the HS medium as showen in Fig(1).

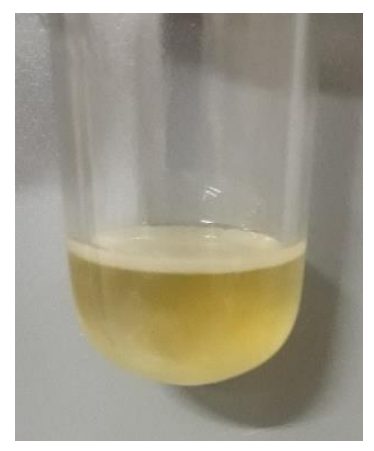

Fig (1): Photograph image of bacterial cellulose pellicle in culture medium HS

Since strain SB3.1 showed the best productivity, it was used in the subsequent studies. As is shown in Fig. (2), under 1000x magnification, the bacterial cells appeared in short rod shape and were Gram- negative. Colony and cell morphology were consistent with the Gluconobacter in Manual of Systematic Bacteriology.
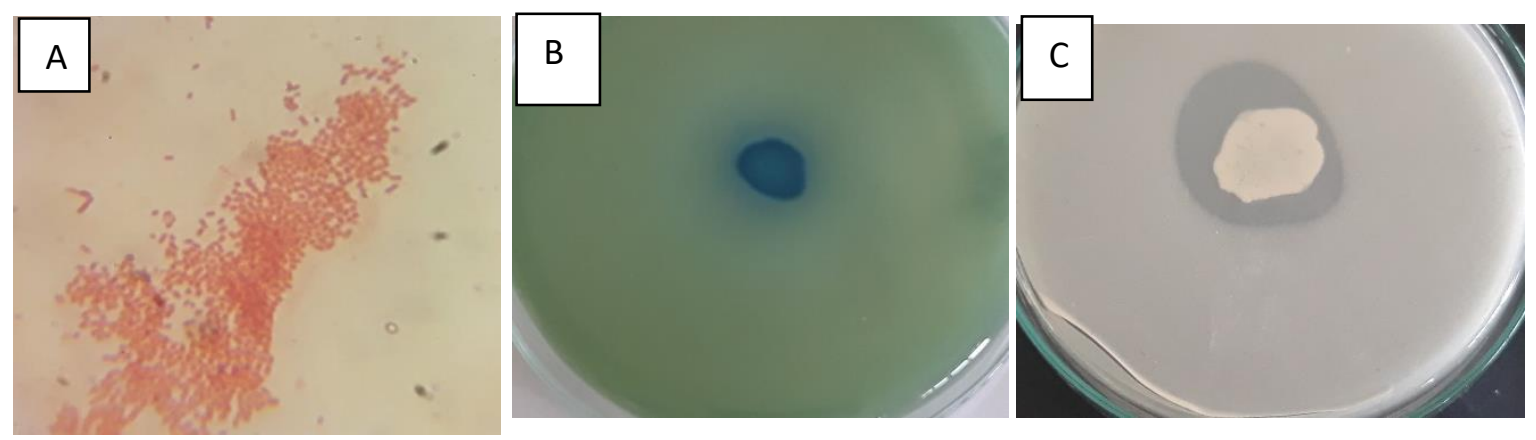

Fig. 2: Cell morphology of strain SB3.1 (A), growth on Passmore medium (B), Growth on Carr medium (C)

In biochemical characteristics analysis, the strain SB3.1 did show the identical physiological and biochemical characteristics as Acetobacter xylinum and reference in Bergey's Manual of Systematic Bacteriology (Table 1). Acetobacter xylinum and reference exhibited minimal BC production when cultured in the medium of Carr and Passmore. However, the strain SB3.1 can produce large amount of BC in Carr and 
Passmore medium, suggesting that the strain SB3.1 is a new strain and named as $K$. xylinus SB3.1.

Table 1 : Physiological and biochemical characteristics of (K. xylinus ) SB3.1

\begin{tabular}{|c|c|c|c|}
\hline & Characteristics & $\begin{array}{c}\text { Acetobacter xylinum } \\
\text { (reference strain) }\end{array}$ & $\begin{array}{c}\text { SB3.1 } \\
\text { Isolated }\end{array}$ \\
\hline 1 & Gram stain & - & - \\
\hline 2 & Production of catalase & + & + \\
\hline 3 & Production of water soluble pigment & - & - \\
\hline 4 & Growth in the presence of 0.35\% acetic acid (pH 3.5) & + & + \\
\hline 5 & Growth on 3\% (v/v) ethanol in the presence of 5\% & + & - \\
\hline 6 & Requirement of acetic acid for growth & - & - \\
\hline 7 & Growth only in the presence of acetic acid, ethanol and & + & + \\
\hline 8 & Growth on the medium of Carr and Passmore & + & + \\
\hline 9 & Growth on carbon source ethanol & + & + \\
\hline 10 & Growth in the presence of 30\% (w/v) glucose & + & + \\
\hline 11 & Production of cellulose & + & \\
\hline
\end{tabular}

comparing with description in Bergey's Manual of Systematic Bacteriology.

The 16s rDNA fragment (1050 bp) of selected strain SB3.1 was amplified by using PCR technique. The analysis of $16 \mathrm{~s}$ rDNA sequencing indicated that $16 \mathrm{~s}$ rDNA fragment from the selected strain SB3.1 showed 99\% similarity with the sequence of Komagataeibacter xylinus NBRC 11664. Hence, the strain SB3.1was identified as member in the Komagataeibacter genus (Fig. 3).

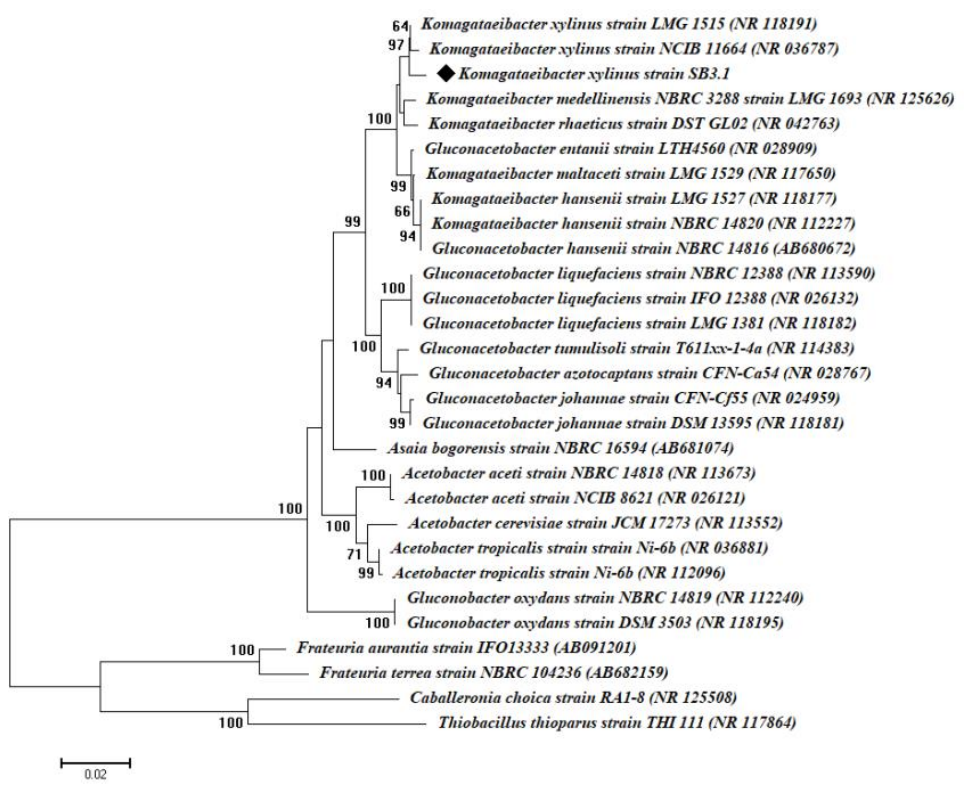

Figure. 3. A phylogenetic tree based on $16 \mathrm{~S}$ rDNA sequences constructed by the neighbor-joining method. 


\subsection{Influence of various growth media on the production of bacterial cellulose}

The results presented in Fig. (4) reveal that the maximum yield of bacterial cellulose was produced in GEM and COM media. Approximately 12.6 and $11.5 \%$ of cellulose yields were observed, respectively following inoculation with the isolate and incubation for 7 days under static conditions. GEM were selected as the best media for production of cellulose as well as yield.

These results are in good agreement with previous reports that cellulose production by Gluconacetobacter strains isolated from various sources produces the highest yield in a medium comprising D-mannitol (Suwanposri et al., 2013).Similarly, many literatures reported the effect of various growth media on the production of cellulose (Mohammadkazemi et al., 2015).

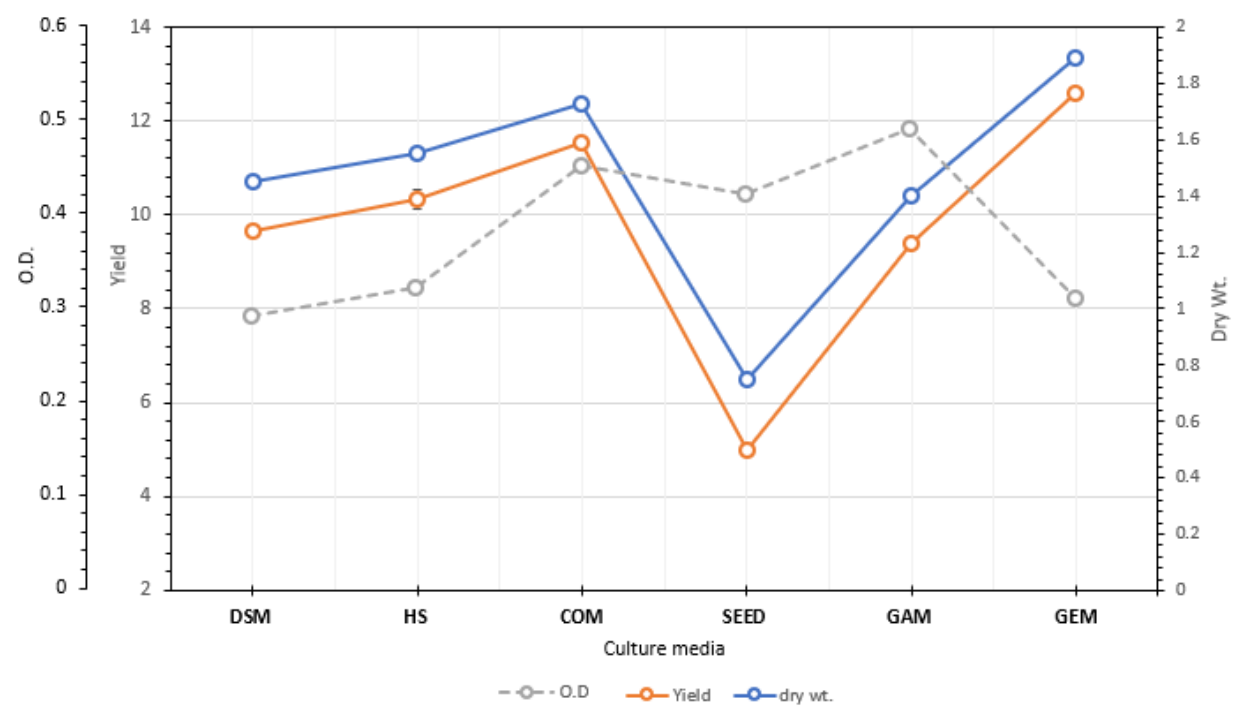

Fig4: Effect of various media on the yield of cellulose produced by $K$. xylinus SB3.1

The effects of the initial $\mathrm{pH}$ of the medium on $\mathrm{BC}$ production were examined. When $K$. xylinus SB3.1 was cultured at $28^{\circ} \mathrm{C}$ for 7 days at various initial pHs of $4,5,6$, 7, 8, and 9, the BC yield at initial $\mathrm{pH} 6.0$ was the highest with $2.4 \mathrm{~g} / \mathrm{l}$ (fig 5). On the other hand, $\mathrm{BC}$ production decreased noticeably below initial $\mathrm{pH} 4$ and above $\mathrm{pH} 8$. Several studies showed that the $\mathrm{pH}$ value range for cellulose production was about 4-9 (Lin et al., 2016) and the optimum $\mathrm{pH}$ for cellulose production varies with the bacterial strains, but was usually attributed to a neutral to slightly acidic $\mathrm{pH}$ range (Bielecki $\boldsymbol{e t}$ al., 2005). 


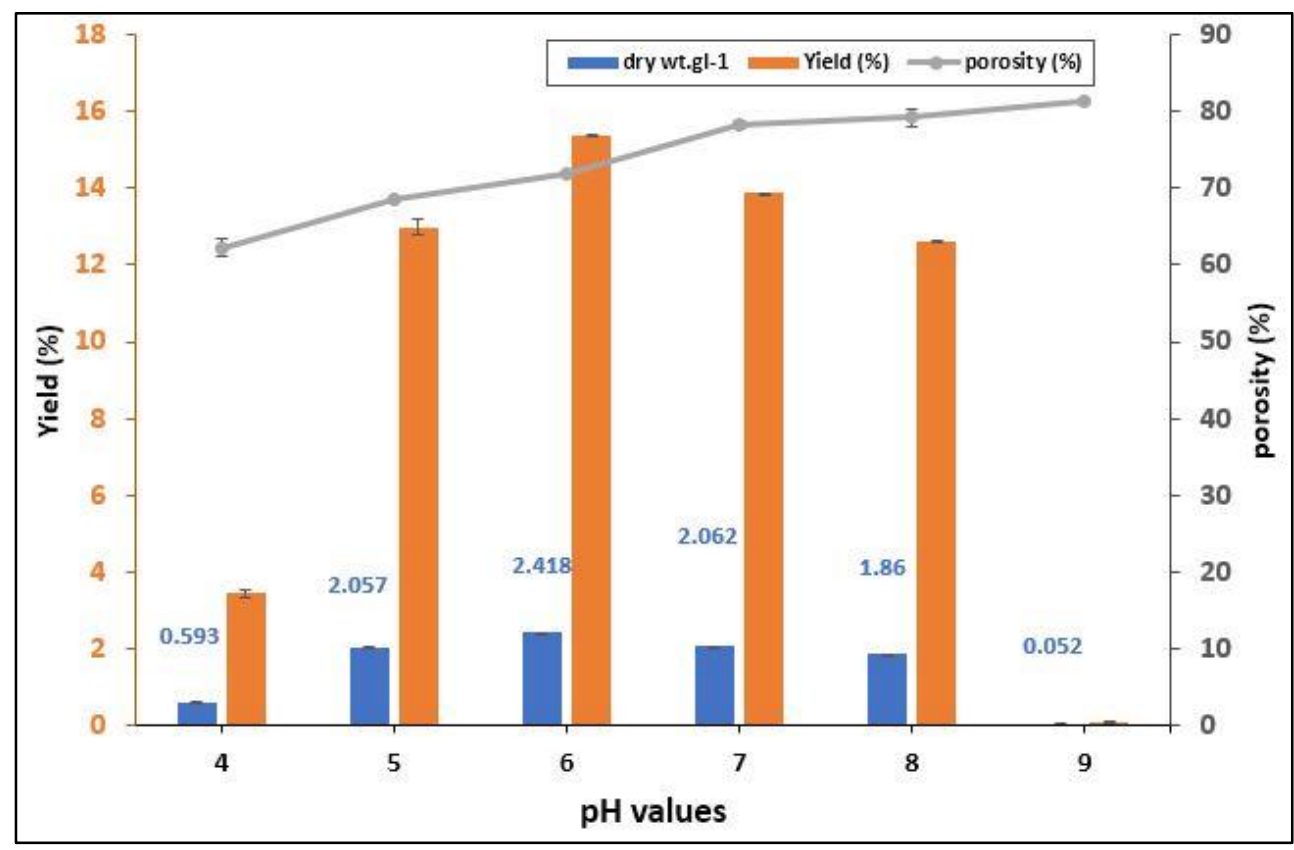

Fig. 5. The effect of variations of $\mathrm{pH}$ values on $\mathrm{BC}$ yield and biomass by $\mathrm{K}$. xylinus SB3.1

SEM results (Fig. 6) provided the surface images of BC produced from $K$. xylinus SB3.1 The morphology of BC samples from $K$. xylinus SB3.1 displayed nano scale network structure (Fig. 4), and its fiber size distribution was around 25-45 nm, slightly smaller than BC from G. xylinus 23769 These results are close to the previous studies (Luz etal., 2006). Scanning electron micrograph results demonstrated that BC produced from $K$. xylinus SB3.1 is similar to cellulose in morphology.

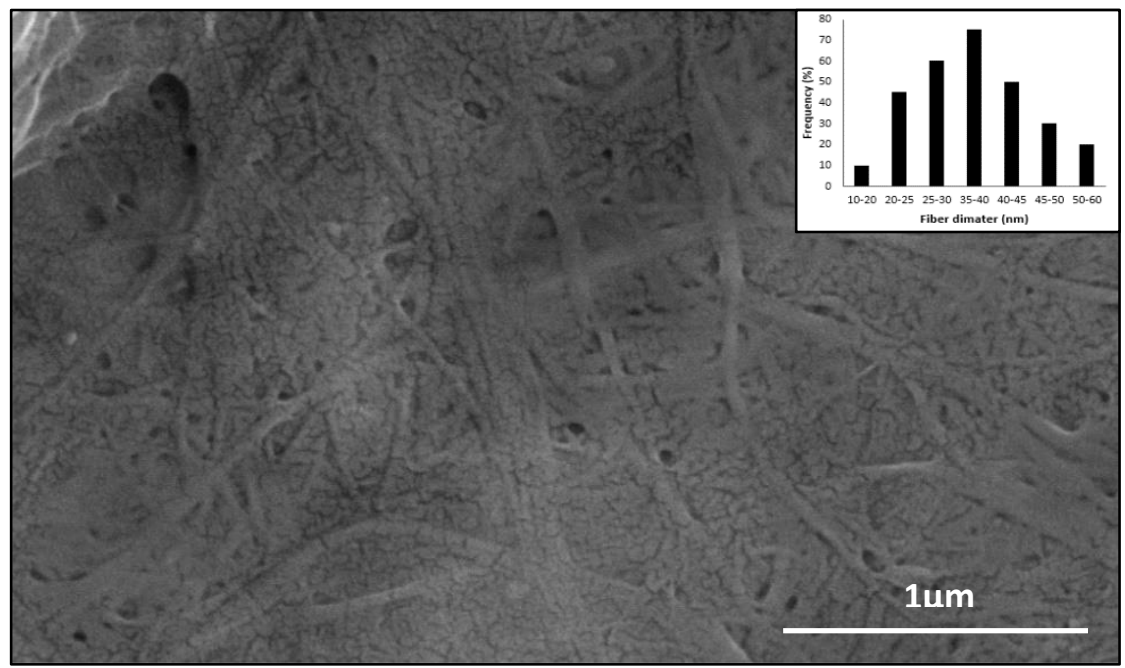

Fig. 6. Scanning electron micrograph (SEM) micrograph of bacterial cellulose produced by $K$. xylinus SB3.1 


\section{Conclusion}

The isolated strain was identified to be K. xylinus SB3.1 based on biochemical tests and 16S r-DNA analyses. The bacterial isolate produced cellulose in traditional and modified media. Significant yield of bacterial cellulose was obtained using GEM culture medium and at pH6. Experiments are in progress to characterize bacterial cellulose and optimization of conditions for its enhanced production.

\section{REFERENCES}

Bäckdahl, H.; Helenius, G.; Bodin, A., Nannmark, U.; Johansson, B.R. and Risberg, B. (2006). Mechanical properties of bacterial cellulose and interactions with smoth muscle cells. Biomaterial, 27(9):2141-2149

Bielecki, S., Krystynowicz, A., Turkiewicz, M., \& Kalinowska, H. (2005). Bacterial cellulose. In A. Steinbüchel \& S.K. Rhee (Eds.), Polysaccharides and polyamides in the food industry (pp. 31-85). Weinheim: Wiley-VCH Verlag.

Brenner, D. J., Krieg, N. R., Staley, J. T., \& Garrity, G. M. (2004). Bergey's Manual of Systematic Bacteriology (2nd ed., pp. 72-77). New York: Springer. Part C.

Chao, Y.; Ishida, T.; Sugano, Y. and Shoda, M. (2000). Bacterial cellulose production by Acetobacter xylinum in $50 \mathrm{~L}$ internal- loop air lift reactor. Biotechnol.Bioeng.68;345-352.

Denise, M.; Rosilene, A.; Adenise, L. and Gilvan, W. (2011). Application of bacterial cellulose conservation of minimally processed fruits. Revista Brasileira de Tecnologia Agroindustrial, 5(1):356- 366.

El-Saied, H; Ahmed, I.; Altaf, H.; Nagwa, A. and Dina, E. (2008). Production and characterization of economical bacterial cellulose."Economical Bacterial Cellulose" Bio Resources, 3(4):1196-1217.

Gamal,RawiaF.;FatmaR.Nasser; Hemmat,M.Abdelhady and M. ELSawy.(1991).Glycerol production by osmotolerant yeast strain using fermentor as fed batch and continous culture techniques. Annals,Agric, Ain Shams Univ. Cairo.36(2):319-321.

H.J. Son, H.G. Kim, K.K. Kim. H.S. Kim, Y.G. Kim and S.J. Lee (2003): Increased production of bacterial cellulose by Acetobacter sp. V6 in synthetic media under shaking culture conditions, Biores. Technol. Vol. 86 (2003), p. 215-219

Hanmougjai,W.; E.Chakeatiirote; W.Pathom- aree;Y. Yamada and S.Lumyoung. (2007). Identification of acid tolerant Acetic Acid bacteria isolated from Thailand sources. Research Journal of Microbiology 2 (2):194-197. 
Hei, CL. (1999). Reduced production of microbial cellolose caused by aggregation of Acetobacter xylinum under shaking culture conditions observation by scanning electron microscope. Applied Chemistry, 3:92-95.

Hestrin, S. and M. Schramm. (1954). Synthesis of cellulose by Acetobacterxylinum.Preparation of freeze-dried cells capable of polymerizing glucose to cellulose.Biochem. J.,58: 345-352

Jagannath, A. ;Kalaiselvan, A. ; Manjunatha, S. ;Raju, P. and Bawa, A. (2008). The effect of $\mathrm{pH}$, sucrose and ammonium sulphate concentration on the production of bacterial cellulose (Nata-de-coco) by Acetobacter xylinum. World Microbiol Biotechnol.24:2593-2599.

Kamide,K.; Y. Matsuda; H. Iijima and K. Okajima (1990). Effect of culture conditions of acetic acid bacteria on cellulose biosynthesis. British Polymer Journal 22: 167-171.

Klemm, D.; Udhardt, U.; Marsch, S. and Schumann, D. (1999). "BASYC Bacterial synthesized cellulose: Miniaturized tubes for microsurgery", Cellulose Polymer News, 24(11): 373 - 380.

Kouda, T.; Yano, H. and Yoshinaga, F.(1997). Effect of agitator configuration bacterial cellulose productivity in aerated and agitated culture. J. Ferment. Bioeng., 83:371 - 376.

Krystynowicz, A. and Bieleck, S. (2001). Biosynthesis of bacterial cellulose and it,s potential application in the different industries, Polish Biotetechnol. News, Copyright by Bio - Tech Consulting.

Kuan, C.; Jeffrey, M. and Ali, D. (2009) .Effect of different additives on bacterial cellulose production by Acetobacter xylinum and analysis of material property. Cellulose, 16:1033 - 1045.

Li, M.; Tian, X. and Chen, X. (2009). Modeling of flow rate, pore size, and porosity for the dispensing-based tissue scaffolds fabrication. Manuf. Sci. Eng. 131(3):34501-34505.

Lin, S.P., Huang Y.H., Hsu K.D., Lai Y.J., Chen Y.K. and K.C. Cheng (2016), Isolation and identifi- cation of cellulose-producing strain Komaga- taeibacter intermedius from fermented fruit juice. Carbohydr. Polym. 151: 827-833

Luz, D.; Carreno, P.; Luis, A. and Alberto, C. (2006). Effect of culture and purification conditions on physicochemical and transport properties in bacterial cellulose membranes, Biomaterials, 27:145 - 151 .

Marzieh, M. and Ali, Y. (2010). Investigation of physiochemical properties of the bacterial cellulose produced by Gluconacetobacter xylinum from date syrup. World Academy of Science, Engineering and Technology 68. 
Mohammad kazemi, F., Azin M. and A. Ashori, (2015) Production of bacterial cellulose using diff- erent carbon sources and culture media. Carbohydr. Polym. 117: 518-523 (2015).

Pacheco, J. ; Yee, S. ; Zentella, M. and Marvan, E. (2004). Cellulosa bacteriana en Gluconacetobacter xylinum:Biosintesisy Aplicaciones. Revista Especializada en Ciencias Quimico - Biolōgicas, 7(1):18 - 25.

Putra, A.; Kakugo, A.; Furukawa, H.; Gong, J.P. and Osada, Y. (2008). Tubular bacterial cellulose gel with oriented ibrils on the curved surface. Polymer 49;1885-1991.

Retegi, A.; Gabilondo, N.; Pena, C.; Zuluaga, R.; Castro, C.; Ganan, P. and Delacaba, K. (2010). Bacterial cellulose films with controlled microstructuremechanical property relationships.Cellulose, 17:661-669.

Sherif, K. and Kazuhiko, S. (2006). The utilization of sugar cane molasses with/without the presence of oligosulfonate for the production of bacterial cellulose. Appl. Microbiol. Biotechnol., 72:291-296.

Sudsakda,S.;W. Srichareon and W. Pathom- aree.(2007). Comparison of three enrichment broths for the isolation of thermotolerant acetic acid bacteria from flowers and fruits. Research Journal of Microbiology2 (10):792-795.

Suwanposri, A., Yukphan P., Yamada Y. and D. Ochaikul, (2013) Identification and biocellulose pro- duction of Gluconacetobacter strains isolated from tropical fruits in Thailand. Maejo. Int. J. Sci. Tech. 7: 70-82 (2013).

Systat Software, Inc. SigmaPlot ${ }^{\circledR}$ software, verssion12.0, San Jose, CA 95110, USA; 2001

Timke, M.; D. Wolking; N. Q. Wang-Lieu;K. Altendorf, and A. Lipski. (2005). Microbial Composition of biofilms in a brewery investigated by fatty acid analysis, fluorescence in Situ hybridization and isolation techniques.Applied Microbiology and Biotechnology 66: 100-107.

Vu, T. N. ; Bernadine, F.; Michael, J. G. and Gary, A. D. (2008). Characterization of cellulose production by a Gluconacetobacter xylinum strain from kombucha. Curr Microbiol, 57:449-453.

White, D.G. and Brown, R.M.(1989). Prospects for the commercialization of the biosynthesis of microbial cellulose. In: Schuerech, C (ed) Cellulose and WoodChemistry and Technology. Wiley, New York.

Yamada, Yuzo; Yukphan, Pattaraporn; Vu, Huong Thi Lan; Muramatsu, Yuki; Ochaikul, Duangjai; Nakagawa, Yasuyoshi (2011). "Subdivision of the genus Gluconacetobacter Yamada, Hoshino and Ishikawa 1998: the proposal of Komagatabacter gen. nov., for strains accommodated to the Gluconacetobacter 
xylinus group in the $\alpha$-Proteobacteria". Annals of Microbiology. 62 (2): 84985

Yamanaka, S.; Ishihara, M. and Sugiyama, J. (2000). Structural modification of bacterial cellulose. Cellulose, 7:312 - 225.

Yamanaka, S.; Watanabe, K. and Suzuki, Y. (1990). European patent 0,396,344A2.

\section{عزل وتوصيف لسلالة بكتيرية منتجة لألياف النانوسيليلوزالمنتجة من فواكة مخمرة}

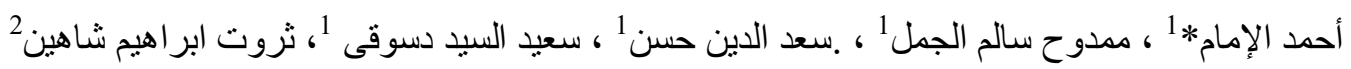

1 قسم النيات و الميكروبيولوجى كلية العلوم جامعة الاز هر

2 قسم الصناعات النسيجية و الياف السيلوز المركز القومي للبحوث

ahmed.alemam@azhar.edu.eg : البريد الاكتروني للباحث الرئيسي

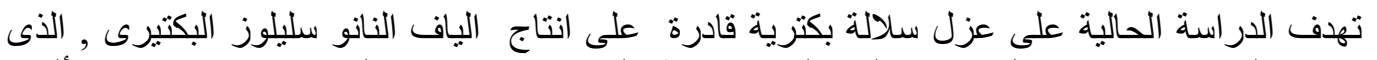

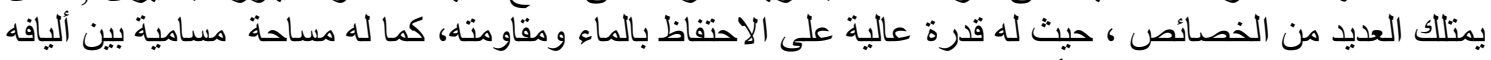

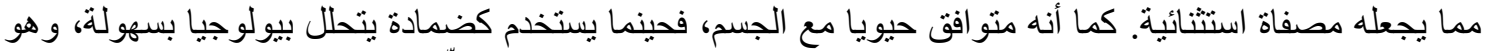

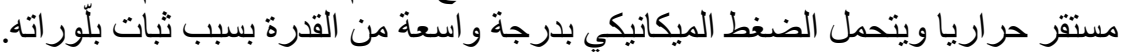

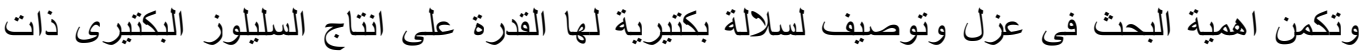

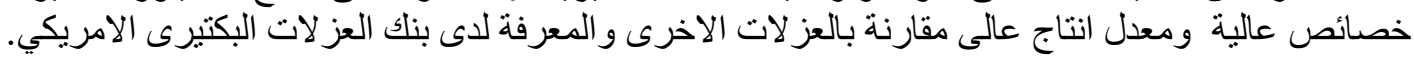

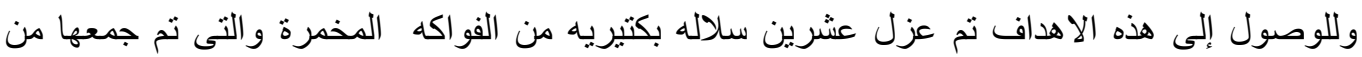

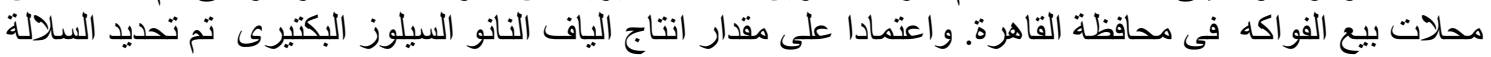

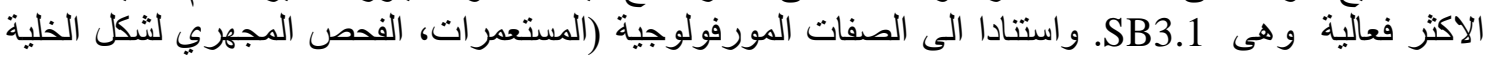

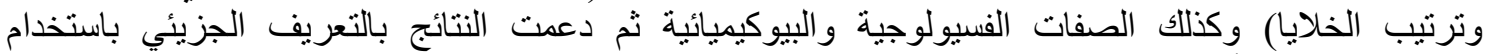

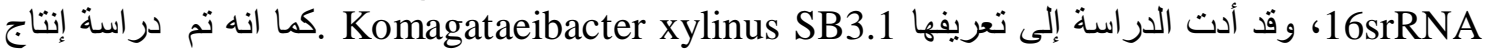

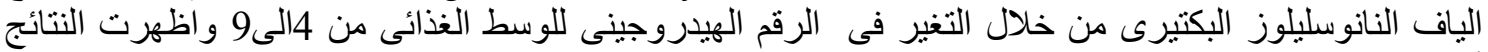

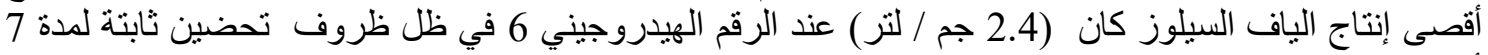

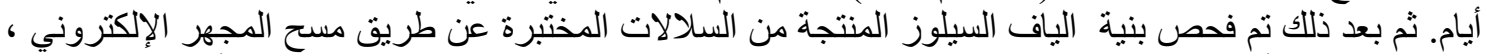

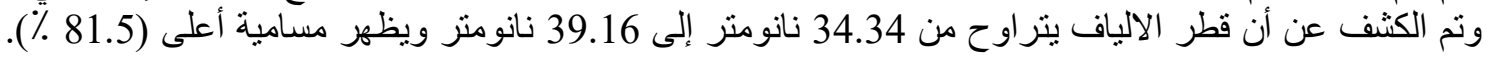

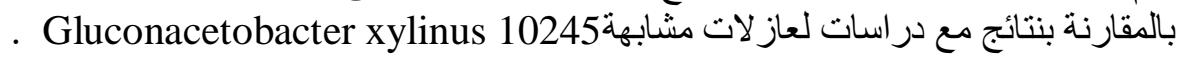

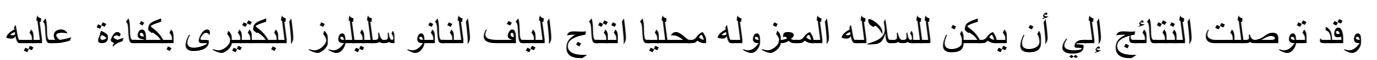

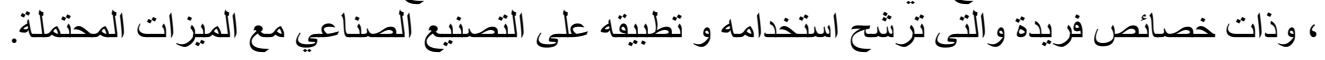

الكلمات المفتاحية : السيليلوز البكتيري، أسيتوباكتر إكسيلينيوم، النانو سيلو، اسيتوباكتر الفاكهة المخمرة 